\title{
Dylan Trigg
}

\section{THE ROLE OF THE EARTH IN MERLEAU-PONTY'S ARCHAEOLOGICAL PHENOMENOLOGY ${ }^{1}$}

\section{Introduction}

This paper aims to chart the importance of the concept Earth in MerleauPonty's late philosophy, specifically as it figures in a series of commentaries on a late fragment of Husserl's widely known as "The Earth Does Not Move" (Merleau-Ponty 2002). As I argue in this paper, the fragment is essential not only for scholars of Husserl, but also for an understanding of the development of Merleau-Ponty's late thinking, especially as it is played out in the lecture notes on nature as well as his unfinished manuscript, The Visible and the Invisible (Merleau-Ponty 2003/1968). As we will see, it is striking if not uncanny how the Earth fragment continues to haunt Merleau-Ponty during the late years of his life, and with each re-reading, the axis of Merleau-Ponty's philosophy seems to turn increasingly away from the horizon of experience to what will become an "archaeological phenomenology."2

Written in 1934, Husserl's fragment is a preliminary study of the relation of the Earth as the ground of being. His Earth, as we will see, is that which renders movement, rest, and thus the structure of the body possible in the first instance in both its kinaesthetic relation with the world and in its intercorporeal relation with others. Against the "modern" (Copernican) tendency to reduce the Earth to a planet among many, for Husserl, the Earth as it is pregiven to experience is no less than the ground of all possibilities.

Merleau-Ponty's "commentary" on the Earth fragment in his lecture notes is as much a dialogue with the dead Husserl as it is a development of his own thinking at the time. ${ }^{3}$ For Merleau-Ponty, Husserl's fragment becomes an opportunity to articulate a series of concepts he was working on at the time of his Collége de France lectures on nature (1957) through to his lectures on Husserl at the same institution (1959-60), and then up to his final incomplete manuscript, The Visible and the Invisible (1960-1961), published three years after his premature death in 1961. Throughout this trajectory in his career, Merleau-Ponty's continuous dialogue with Husserl is aimed at grounding Merleau-Ponty's own radical ontology, an ontology that seeks to incorporate Husserl while also recognising that only through betraying Husserl's transcendental idealism is a genuine ontology possible.

It is, perhaps, no coincidence, therefore, that faced with the Husserlian fragment on the Earth as an arc-or better arche (origin)-, Merleau- 
Ponty will term his method of eliciting the unthought element in Husserl an "archaeology" (2002). By phrasing his late phenomenology as archaeological, Merleau-Ponty not only accents the importance of origins but also points to the ground in which those origins are buried while at the same time remaining constitutive of the ground itself. Thus, if Merleau-Ponty is able to pronounce his phenomenology as a "phenomenology of origins" in the Phenomenology of Perception, then it is only in his late thinking that his thought gains the archaeological foundations able to support this claim (Merleau-Ponty 2012, xxxii).

In order to assess the role of this fragment within Merleau-Ponty's thinking, three stages are mapped out. First, I offer a preliminary exposition of the fragment itself, focusing in particular on the role of the body in its coconstitution with the Earth. From this account, a series of questions opens up that are left unresolved in Husserl, not least the question of whether the Earth as playing a constitutive structure in the body can be understood in terms of transcendental phenomenology alone.

Accordingly, in the second part of the paper, I turn to both Merleau-Ponty's lectures on nature and also his specific lectures on Husserl as they are collected under the title Husserl and the Limits of Phenomenology (Merleau-Ponty 2003/2002). Each of these lectures presents us with a different treatment of Husserl, and the difference becomes vital in Merleau-Ponty's own ontology. For what is at stake in the late reading of Husserl is the departure from Husserlian phenomenology to what will become Merleau-Ponty's "archaeological phenomenology," a term I will explicate in time.

Thus, in the final part of the paper, I sketch out how this archaeological thinking is rooted in the Earth fragment, without a consideration of which, any understanding of Merleau-Ponty's late thinking would remain incomplete. My argument can be formulated as follows: Merleau-Ponty's account of the Earth is Husserlian insofar as it reinforces the primordial "ground ( $\mathrm{sol}$ ) of experience" but at the same time marks a departure from Husserl insofar as the Earth registers a brute or wild layer that resists phenomenology (cf. MerleauPonty 1964b, 1968). This notion of a brute and wild being (l'être sauvage), which Merleau-Ponty owes in part to the influence of Schelling, ${ }^{4}$ refers to an elemental Being, which is not only anonymous but also anterior to the subject and in this respect, fulfils an archaeological phenomenology.

\section{Husserl's Earth}

Before we turn to Merleau-Ponty's ontology, let us begin at the origin: Husserl. Husserl begins his fragment by stating the importance of the topic, going so far as to preface his notes with the claim that the "following pages are...foundational for a phenomenological doctrine of the origin of spatiality, corporeality, Nature in the sense of the natural sciences, and therefore for a transcendental theory of natural scientific knowledge" (117). Even if the 
fragment is a preparatory study, then the inclusion of spatiality, corporeality, and the scientific knowledge of Nature are tied together in his specifically phenomenological account of the Earth. The account is specifically phenomenological, as Husserl positions himself in contrast to a naturalistic and "modern" account of consciousness, whose concern is particular objects in the world rather than the very ground(ing) of those objects. Foundational, in this context, therefore, refers not only to the foundational of a phenomenological enquiry but also to the foundation or ground (Boden) of experience itself. ${ }^{5}$

His point of departure for establishing this foundation is to begin with the surrounding world as an infinite space; that is, a space that "is not completely conceived, represented, but that is already implicitly formed" (117). This occurs on a localised level in terms of the borders between city and countryside, between individual countries, between continents, and then of the Earth itself. On this initial phenomenological reduction, the Earth is given as a unity taken from the standpoint of the individual subject, who unifies "the experiential field... in a continuous and combined experience" (118).

From a "modern" (Copernican) perspective, the Earth is a discrete star set against the backdrop of "infinite space" (118). More than this, it is a body, though a special kind of body. Not one that can be approached in its wholeness - Husserl is writing, of course, before the famous Blue Marble photo taken in 1972 by the crew of Apollo 17-but a body that is the "experiential ground of all bodies" (118). Our everyday relationship to the Earth, as Husserl presents it, is not a bifurcated relationship, whereby the Earth is simply one star among many. Nor is it a fragment of materiality on which other smaller fragments exist. Rather, the Earth is a ground (Erdboden) and in this respect, a constitutive structure in our experience of spatiality.

To this end, the Earth, considered as originary phenomena, "does not move and does not rest" (118). It is only in a relational way that movement and rest come to have an ontic significance. Phenomenologically, therefore, Husserl is obliged to place the Copernican perspective of the Earth, as a thing located into cosmic space, secondary. If the Earth does not move, then movement becomes a relation - a "certain relativity" - which is tied up with my "corporeal flesh" (121). All of which is possible thanks to the fact the Earth is experienced, not as a localised body - at least not a body that can be understood in terms of other bodies - but as a ground of bodies. Put another way, if the Earth is not in movement, then this is only because it is the very ground for the possibility of movement, and thus for experience.

Seen in this way, Husserl's Earth is, before anything else, a given of experience. Considered in this pre-thematic way, the Earth assumes its importance as a spatial origin of the very structure and possibility of bodily existence, without which movement and rest would not be possible. The task, such as it is phenomenologically, is to return to the Earth itself-the Earth that underpins all subsequent scientific reductions of the same planet to a material entity and in this respect, to reinforce its validity as a relation. 
With this background, Husserl is now in a position to consider the relationship between the Earth as a singular planet and the human bodies that inhabit that world. Central to this preliminary phenomenology of the Earth is the question of whether or not there can be another Earth. As we have seen, without the Earth as a foundation, the formation of the body would be impossible. Against this claim, the question of another Earth comes up in two ways. First, if the Earth can be conceived as a body, then it is only in relation to another Earth. Without this other Earth, the original Earth retains its validity as an originary foundation but resists being phenomenologically conceived as a body in its own right.

Second, the more pressing question to the existence of another Earth is the human body's relation to the Earth we already know. Such a question draws to the light the singularity animating the role of the Earth as being constitutive of our experience of bodily space. Can another Earth assume the constitutive role the present Earth does now, and if so what are the implications for corporeality as we know it?

For the present purposes, we shall give attention to the second question. ${ }^{6}$ The question of whether "outer bodies" can, as it were, leave the Earth behind, is approached via the "same earth" that is shared between bodies. This common foundation unites my body with yours, coupling us not only as intercorporeal subjects but also as inter-earthly subjects, too. It is at this juncture that Husserl embarks on a compelling thought experiment. He asks us to imagine a bird that can fly beyond the Earth, there in this "carnal flight-vessel" and now able to see the Earth as a "large spherical body" (125). Throughout this voyage, even on a "flying machine" able to "experience" stars, the body - be it human or bird - remains tied to the Earth, from where it receives its bearings and origins.

As primordially constituted by the Earth, our sense of being endowed with earthly bodies in an earthly space is beyond transcendence. The Earth, in its geological and temporal depth, marks the existence of my flesh, constitutes the body in such a way that whatever secrets the Earth conceals are also concealed within myself. As Husserl has it, our own history as belonging to a particular homeland, is overarched by the homeworld of the Earth, to which we each belong and can never escape without already defining ourselves as having left the Earth, as he writes: "All developments, all relative histories have to that extent a single primordial history of which they are episodes" (127). This distinction between a macrocosmic and a microcosmic history ties over into the body, which presents itself as having two orders of time: that of the lived and personal and that of the impersonal and earthly, the latter being beyond experience and thus marking a prehistoric order.

In the speculation of another Earth, therefore, Husserl's account of the history of the body ties us with an origin that is beyond the subject. Of other planets, Husserl is prepared to suggest that the "interpretation of the world in human history, in the history of the species, within the evolution of the individual and people, [is] an obviously accidental event on the earth which might just as well have occurred on Venus or Mars" (129-130). In turn, 
other planets would simply assume the constitutive role that the Earth does presently.

Likewise, if I am an astronaut who decides to settle on Mars as my "primordial home," then at no point does my colonization and subsequent approbation of Mars as my homeland strip me of my "terrestrial humanity" (13). As he writes decisively: "There is only one humanity and one earth - all the fragments which are or have been separated from it belong to it" (130). Husserl's Earth, such as it is, is fundamentally sculpted by its human constitution, just as humanity is fundamentally sculpted by its earthliness. This does not discount the "modern" view of the Earth as a body, but instead presents us with two sides of the same face: a transcendental Earth and an objective Earth.

Toward the end of the fragment, Husserl makes a curious intervention in this line of thought, as though in passing. Developing a series of objections against the primordiality of the Earth - the possibility of another Earth and the fragmentation of the Earth being two possible objections - he then adds another one from the perspective of science, namely "that entropy will put an end to all life on earth, or that celestial bodies will crash into the earth, etc." (131). The thought being that the phenomenological validity of the Earth as ground would lose its legitimacy when reduced to the status of a thing. We will return to this passage below, as it merits an incisive comment from MerleauPonty and also assumes a special place in our own treatment of Merleau-Ponty.

To summarise our findings so far, Husserl presents us with an account of the Earth as a foundation. It is a foundation in at least two respects. In the first respect, the Earth is a foundation in that it renders movement and rest possible by establishing a relational axis between the body and the Earth as ground. In the second respect, it is a foundation in that it constitutes the specificity of the body as having an origin. So long as there are human bodies, then those bodies will remain tied to the Earth, which can never truly be left behind, even given the prospect of terraforming another Earth other than our own.

A series of questions opens up in light of these claims. Is the Earth primarily given as a unitary foundation for corporeal existence or does Husserl underplay the structure of the Earth as a discrete body? For that matter, what are we to make of Husserl's remarks on the origin of the body as being transcendentally constituted by the Earth? Can we conceive of the body aside from the Earth? And likewise, can we conceive of the Earth without the body? ${ }^{7}$

It is to these more enigmatic questions that we can now turn to MerleauPonty. As mentioned above, there are two specific pieces of writing from the late Merleau-Ponty that will allow us to map together not only his response to Husserl but also his modification of Husserl's account of the Earth. Accordingly, in the following section, we will turn to Merleau-Ponty's lecture notes on Husserl as they figure in both the lectures on nature from 1956-1957 and the subsequent notes from his course on Husserl from 1960. We will then end by sketching the invisible lines of thought in this assemblage of fragments and notes. 


\section{Originary Objects}

Merleau-Ponty's course from the Collège de France lectures on nature contains a rich pool of thought that traces the theme of Nature from the Stoics to quantum theory and then onto Merleau-Ponty's own ontology, which will fold into his account of the flesh. The collected notes are divided into three parts. The first two courses are on the "concept of nature" and "modern science and nature," each course not written by Merleau-Ponty himself but assembled together by an unknown auditor or student. Only the third course on the human body is written by Merleau-Ponty, and, as mentioned above, even there the notes are written for himself and thus at times highly inscrutable.

Of concern to us presently is his discussion of Husserl in the first part of the book. Merleau-Ponty's initial discussion of the late fragment comes via a discussion of the body as positioned in space (Merleau-Ponty 2003, 74). This discussion is consistent with the account of the body as it figures in both the earlier Husserl and the earlier Merleau-Ponty. Here, Merleau-Ponty outlines how the lived body coincides with the things in which the body lives, meaning that there is a "carnal unity" that accompanies my experience of the world (74). This unity in turn leads to Husserl's discussion of one hand touching another, which Merleau-Ponty famously employs in The Visible and Invisible. It is thanks to the fact that the body is an "absolute here" - a phrase that stems from the earlier Phenomenology of Perception - that this interchange between the body as a subjective organ of perception and the body as an objective organ perceived becomes possible. Around the body, the surrounding world remains relative to the irreducibility of my corporeal life, a life that not only includes my relation to my own body but also to others (75). The other enters the scene of my corporeal life not as an analogy of my existence, but as an extension of corporeality, of which both self and other partake in what Merleau-Ponty would term an "interworld" (76).

All of which is a prefatory context for the ensuing discussion of the Earth, which marks a distinction between Husserl's early and late thinking. As Merleau-Ponty notes, added to this division between self and other in their joint corporeality is the gradual subjectification of "quasi-objects" in Husserl (77). Such "quasi-objects" would include the Earth. Here, Merleau-Ponty follows Husserl's line of thought closely, regarding the Earth as "the living stock from which the objects are engendered" (77). Moreover, because it serves to contain all the possibilities of objects, it establishes itself as a "cradle" for those things (77).

Yet in "situating the Earth among the planets," this primordial ground has been forgotten. Or, at least, apparently forgotten. After all, what Husserl shows us is that the Earth as a ground can never be forgotten so long as we remain bodily subjects, as Merleau-Ponty remarks after Husserl: "To think two Earths is to think one same Earth" (77). In this respect, in both Merleau-Ponty and Husserl, the Earth is not doubled but instead expanded as an all-encompassing "carrier of all the possible," which is beyond transcendence (77). 
We now come to a critical problem, both for Husserl and for MerleauPonty. The problem is one that we left hanging in our earlier engagement with Husserl, namely: what becomes of the Earth when humans cease to exist and thus references also cease to be? The problem is important because it pushes to the surface the very limit the extent to which the Earth and the body are co-constituted. Not only this, but it also thematizes the question of how the Earth -if we take the Earth as not only as an Urheimat (primal home) but also an Urhistorie (primal history) - can be considered as both phenomenological and non-phenomenological in structure.

We already know that Husserl formulates the Earth as an original ground, which is beyond transcendence. In the face of a destroyed Earth devoid of its humanity, Husserl only reinstates the validity of transcendental phenomenology by drawing an analogy between a fragmented Earth and the process of dying. In the case of the death of others, a unity is retained insofar as "recollection permeates life -I still live," and thanks to the power of reiteration I am able to retain the presence of the "We" (Merleau-Ponty 2002, 131). With this, Husserl is setting up his counter-response to the notion of an Earth that is in the first instance a mass of material reality, and that alone.

Husserl here turns to a transcendental argument for the existence of the "constituted world," asking directly "What sense could the collapsing masses in space...have, if the constituting life were eliminated" (131). It is the constituting ego as a transcendental entity that "precedes all actual and possible beings, and anything existent whether in a real or irreal sense" (131). For this reason, any such reference to the finitude of the Earth's collapse hinges at all times on a prior positing of the transcendental structure of the constituting ego, stating that "What belongs to constitution is, and is alone, the absolute and ultimate necessity" (131). And this prehistorical, prepersonal origin takes root in the body, which is prior to scientific inquiry and therefore cannot be augmented even in experiential terms, as Husserl has it of the experiential quality of time: "The constituted time of the world, more particularly, conceals itself in itself psychological time, and the psychological refers back to the transcendental" (131). In other words, the experiential level of existence, in which the body is bearer of time, hinges at all times on a loop folding back upon the transcendental possibility of time. Such a time operates at another level from that of our own existence; that of a constituting level.

It is important to note here that Husserl's usage of "constitution," especially as it figures in the period of The Crisis of European Sciences, refers to the way in which particular things are given their meaning and sense (Husserl 1970). If the world itself is not reducible to the constitution-given this would entail a form of idealism - then this does not mean that consciousness can step outside of the correlation with the world. Rather the world as the sensible world of meaning and understanding is such only that it can be understood with respect to the constituting ego. Meaning appears here, therefore, not as something fabricated by consciousness, but something that is revealed in relation to consciousness. 
Given the role of constitution for Husserl, the world is always already there for us, since without the world there is no body and no body without the world. It is on this point that Merleau-Ponty appears - at least, initially - to agree with Husserl, writing of this passage that: "We have to admit then that the world is not an appearance in relation to the appearances of pure things, but on the contrary that it is founding in relation to these pure things" (Merleau-Ponty $2003,78)$.

In turn, this leads Merleau-Ponty to present Husserl's philosophy of nature as one of retaining a fidelity to originary phenomenon, of which the subject him or herself "continues" but does not "initiate" (78). In this way, Nature emerges, not as the Urheimat itself, but instead as meeting of body and Earth, and thus of "interiority" and "exteriority," which all subjects partake of in a primordial way (78). This "common primal presence," so Husserl remarks in a passage from Ideas II cited by Merleau-Ponty, “...is nature in the first and original sense" (78).

Husserl's account of the constituting ego is problematic on several grounds. Above all, though, it is unclear how Husserl is able to account for the "original sense" of Earth so long as he remains tied to the idealization of the constituting ego. Indeed, the paradoxical quality of the Earth without bodily subjects only remains paradoxical so long as Husserl commits himself to the primacy of the ego as assuming a constituting role. To be sure, as Merleau-Ponty indicates, the term "constitution" assumes a multiplicity of meanings in Husserl: "The word 'constitution' undoubtedly has a very large meaning in Husserl, who always distinguished a constitution by acts from a 'latent' constitution" (79). Yet it is precisely this latter constitution or intentionality that remains beneath and prior to the constituting ego, which is both underplayed and underdeveloped in the late Husserl, albeit even if Husserl presents this series of thoughts in a "preparatory" way (79).

\section{At the Limits of Phenomenology}

The suggestion here of the need for another phenomenology - what he will proceed to describe in psychoanalytical terms as a "phenomenology which descends into its own substratum" - is where Merleau-Ponty seems to leave us at the end of his notes on Husserl and nature (Merleau-Ponty 1993, 70). It is at this very intersection between a latent intentionality and a constituting ego that Merleau-Ponty will depart from Husserl. As we turn from the lectures note on nature to the later lectures on Husserl, Merleau-Ponty will stage a series of subtle shifts in his reading of the "The Earth Does Note Move" fragment. Indeed, Merleau-Ponty's course notes collected in Husserl at the Limits of Phenomenology present us with not simply with a commentary on Husserl but 
an expansion of Merleau-Ponty's own philosophy, which dovetails with his thinking in the unfinished The Visible and the Invisible.

As with the course notes on nature, Merleau-Ponty begins by following Husserl in maintaining a view of the Earth as that which "engulfs" the corporeal subject, establishing a "unity of history," which results in a reinforcement that "every other planet is earth" (Merleau-Ponty 2002, 68). Following this, we have the issue of the Earth as forgotten; that is, the Earth as the "ground of experience" which can be reclaimed through a careful phenomenological reduction. Intersubjectivity - or rather, intercorporeality - enters the scene by way of offering an access out of a "pre-Copernican world," with the other assuming the appearance of an objective body who in turn experiences me in their flesh also as an objective body. All of which is possible thanks to the fact that "my corporeality is communicable" (71). Thus, Merleau-Ponty retraces Husserl's account of the flying bird, which at all times retains a primordial connection to the "true Boden" (72).

If Merleau-Ponty maintains an alliance to Husserl in this late thinking, then his motivation for doing so is not simply to interpret Husserl on his own terms. It is in the final few pages of these lectures that Merleau-Ponty instigates a departure from Husserl in a section titled "ontological scope of this analysis" (73-76). Merleau-Ponty remarks at the outset of this section that a "new type of being is unconcealed" in the relation between Earth, body, and intercorporeality (73). This new type of being, which is evident in the very formation of the stars and the Earth as a ground, upon which my corporeality is implanted onto the "Homeland-Being," exists only as an "idealization" of a "terrestrial relation to the ground" (73). The ground contains its own history, and a history that if it is able to be integrated into subjectivity, then it is only because such a relation takes place at the level of a "preobjective relation among humans and upon the preobjective relation of humans to the earth" (73). This carnal prehistory is resistant to any idealization that takes place in relation to the Earth, where the Earth is considered as a phenomenal entity: "This Earth is the arche. i.e., the reserve from which all life, all future, all history can issue" (74).

At stake here, then, is an attempt to move beyond - both prior and beneathHusserl's constituting ego to a level of latency that accords a reality to the Earth resistant to corporeality despite- or because - of the constitutive role the Earth plays for the subject. At the conclusion of the lecture, Merleau-Ponty's distance not only from Husserl but also from transcendental phenomenology more broadly becomes abundantly clear, as he writes:

All of this, this philosophical dimension of the Umwelt... of the world and of the mind before their correlative idealizations - is really different from an idealism; it is the "constitutive" genesis which is first and in relation to which idealities are constituted (75).

This "constitutive genesis" marks an explicit turn from Husserlian transcendental phenomenology to what will become Merleau-Ponty's own 
archaeological phenomenology concerning the prehistory of perception. If these two frameworks operate on different levels, then this does not entail they are diametrically opposed, and as Merleau-Ponty notes from early on, Husserl was already attuned to the notion of a "intentionnalité opérante" (operative intentionality) from the outset (cf. Merleau-Ponty 2012, 440-441). ${ }^{8}$

Despite this linage, when Merleau-Ponty returns to the problem of a "world before man" at the end of the course notes on Husserl, then his tone has shifted from the earlier comments in the nature lectures. This time, he admits that "there is a paradox only if we first realise \{in itself?\} the universe of idealizations" (76). Thanks to the fact that Husserl had "enclosed" himself "in the dimension of the "consciousness' of the absolute Ego," he retains a fidelity to the "realist-causal order and the idealist-constituting order" (76). At the expense of this view, what is overlooked is the project that Merleau-Ponty himself adopts - "turning both [orders] not into a physical world relative to the idealistic Sinngebung (giving meaning), but into two correlative aspects of Being" (76).

It is precisely this search for a latent Being - and a search that renders the very distinction between transcendental idealism and naïve realism possiblethat leads Merleau-Ponty to develop an ontology of his own, which can no longer be classified under the simple term "phenomenology." Merleau-Ponty's reading of Husserl radicalizes the latter by rendering the Earth a pre-object, which, having been transformed into an external object, is reclaimed, not through a reduction of the transcendental Ego, but through returning to the primal arche of the Earth itself.

If both Merleau-Ponty and Husserl are both concerned with the origin of the body as bound to the Earth, then there is nevertheless a radical difference in where each of these philosophers locates the primordial origin. For Husserl, the primordial ground remains in the constituting Ego, thus positioning himself in the tradition of transcendental phenomenology he sought to overcome. Merleau-Ponty, on the other hand, presents us with an account of the Earth that opposes this leaning toward idealism. He does this, not through accounting for the Earth as an insurmountable thing-in-itself, less even as a mass of materiality, of which the contingent outcome is human corporeality. Rather, the primal Being that Merleau-Ponty locates is one that will be developed elsewhere in the elemental ontology of the Visible and the Invisible, especially as it figures in his late philosophy of nature as revolving around themes of latency, verticality, and depth.

Already, however, the germs of this primordial ontology are evident in the course notes on Husserl where he speaks of "two correlative aspects of Being," and as such, it is impossible to consider terms such as "Earth" and "primordiality" without invoking the adjoining notion of "Nature" as an elemental structure that resists transcendental phenomenology (76). Indeed, the Being in question is interchangeable with what Merleau-Ponty terms "Nature," insofar as it designates that which renders carnality possible at all without at the same time being isolated to a metaphysical world in its own terms. 


\section{Toward an Archaeological Phenomenology}

Already we see Merleau-Ponty breaking from Husserl in his attempt to move not only beyond transcendental idealism, but also beyond a model of phenomenology that retains the primacy of the consciousness-world distinction. In turn, this leads Merleau-Ponty to develop a sense of the Earth as a primordial source that is not reducible to the transcendental subject but nor is it a thing-in-itself transported to another realm. The Earth here, such as it is presented in a sketch like form, assumes a presence somewhere between these polarities, situated in the same shadowy realm where Merleau-Ponty himself is positioned in respect to Husserl- "the reflections, shadows, levels and horizons between things" (Merleau-Ponty 1964b, 160). The task now is to develop this shadowy phenomenology by exploring how the Earth fragment plays a formative role in Merleau-Ponty's archaeological phenomenology.

My usage of "archaeology" here refers to an orientation in Merleau-Ponty's philosophy, which can be described as a study of the pre-theoretical or primitive layers that are constitutive of corporeal perception - and for this reason, render experience possible-yet at the same time remain irreducible to experience (cf. Merleau-Ponty 1964). ${ }^{9}$ Methodologically, what is at stake is the importance of conducting what Merleau-Ponty famously terms in the Phenomenology of Perception, a "phenomenology of phenomenology" precisely through addressing the limits of what can be thematized (Merleau-Ponty 2012, 382). The archaeological orientation of Merleau-Ponty's philosophy means developing a method of inquiry that is alert to the "infrastructure" underpinning meaning and sense while at the same time remaining recognising the edges of descriptive inquiry.

To be sure, while this archaeological phenomenology finds its clearest voice in Merleau-Ponty, the seeds of it were already germinating in Husserl, whose studies of geology was not only evident in his reference to "strata," "stratification," "terrain, and subsoil," 10 but was also central to his philosophy more broadly, as Eugen Fink writes: "Husserl always regretted that the expression which truly captures the essence of philosophy had already been taken over by a positive science, that is, the expression 'archaeology"' (cited in Merleau-Ponty 1992, 187). It is precisely in the thinking of Merleau-Ponty that Husserl's incipient archaeology becomes realised in an analysis of the "hither side" of perception.

In turn, this notion of archaeology can only be considered within the context of both Merleau-Ponty's late turn to psychoanalysis and also his usage of wild or brute being as attempting to capture that which phenomenology itself cannot, namely: "That primordial being which is not yet the subject-being nor the object-being and which in every respect baffles reflection" (Merleau-Ponty 1970, 65-66). That Nature cannot be apprehended directly means that it then becomes phrased in terms of a resistance to reflection. ${ }^{11}$ Both implemented and implicated by brute being, the subject is at no point truly able to transcend the primordial ground or soil from which she is structured and constituted. 
Entering onto the scene of the world, the subject's appearance merely reinstates a prehistory that was there long before thought itself initiated the process of attempting to understand this genesis. Throughout, the world of brute existence perdures in time, silently.

This move toward the unreflected and primordial is, of course, present from the inception of Merleau-Ponty's philosophy of origins. Indeed, the arc of Merleau-Ponty's thought shifts gradually from a primacy of consciousness to what will become in a sense the primacy of unconsciousness (cf. MerleauPonty 1968, 253/200). Because of this, with each phase of deepening this work of origins, Merleau-Ponty moves to varying layers and levels of the body, until at the end, the primordial strata of wild being joins with the mute body $-\mathrm{a}$ body that in every sense articulates the "past which has never been present"that assumes an archaeological status in subjectivity, leading him to write of his philosophy as occupying a "process similar to that of an archaeologist" (Merleau-Ponty 2012, 252/1964a, 5).

It is no coincidence, then, that the late language of archaeology folds over into the language of psychoanalysis. Thus, in the "Preface to Hesnard's L'Oeuvre de Freud," Merleau-Ponty will speak of the unconscious in terms of an "archaic or primordial consciousness...that we have not integrated" (Merleau-Ponty 1993, 67). This failure to integrate the "intemporal" and the "indestructible," as he writes of the unconscious element within us, does not simply mirror Merleau-Ponty's archaeological phenomenology in terms of attending to the non-phenomenological or "brute" dimension of Nature, but rather converges to the point where psychoanalysis and archaeology become two sides of the same procedure, leading him to speak of a "consonance" between each method where both aim toward the "same latency" (71.Italics in original)..$^{12}$

In light of this, it is no coincidence that archaeology is the middle ground for both phenomenology and psychoanalysis, not only in terms of methodology but also in respect of the analogy itself. For this reason, Merleau-Ponty's treatment of this relation is telling given he speaks of phenomenology and Freudian psychoanalysis as sharing "our archaeology" (71). In each case, Merleau-Ponty is attempting to trace how an unreflected-or unconsciouscorporeality can grant access to brute being without collapsing that primal layer back into a consciousness-world distinction that marked the Phenomenology of Perception and its commitment to intentionality.

For Merleau-Ponty, then, archaeology — and thus psychoanalysis - signifies less the retention of the past by a personal subject, and more the hermeneutic act of interrogating an impersonal structure, which allows the past to be retained in the first place. In this respect, the past here is not one to be considered as a lost horizon of experience, but instead co-existent in the verticality of timethat is, a time that is contemporaneous with the past and present as being coconstituted.

The convergence of phenomenology and archeologically is especially evident in the important essay, "The Philosopher and His Shadow," where the 
role of the Earth fragment continues to exert a hold on Merleau-Ponty (MerleauPonty 1964b). And indeed, it is precisely in this essay that the connections between Earth, brute being, and archaeology (and therefore psychoanalysis) can be made. ${ }^{13}$

Up to the very end, Merleau-Ponty is not entirely able to free himself of Husserl, but instead manages to find in the master thinker the germs of an ontology that will become Merleau-Ponty's own. In this rich essay, MerleauPonty famously attempts to conceive of an "unthought-of-element" in the figure of Husserl at the "end of [his] life" (160). ${ }^{14}$ Doing so, Merleau-Ponty positions himself in relation to a "new turn in Husserl's thought," marked by a "primordial faith" that is able to "give us not a representation of the world but the world itself" (163). The term "faith," of course, reappears more centrally in The Visible and the Invisible in terms of a "perceptual faith" (Merleau-Ponty $1968,3)$. In that text, Merleau-Ponty uses the term in an indexical way to mark "what is before any position" (3). In each case, what is at stake is a world before thought, a sensible world delineated by its visibility and continuity, and apprehended by a faith irreducible to science (12).

On the following pages, Merleau-Ponty thematizes this faith in a pre-world within the context of Husserl's unfulfilled gesturing toward the "pre-theoretical layer," on which various idealizations, such as those that we have already seen in the Earth fragment, form (Merleau-Ponty 1964b, 165). Once more Merleau-Ponty is faced the central epistemic problem of his philosophy: how to gain access to the unreflected ground of experience without re-inscribing that origin as theoretical abstraction? Hence the question emerges: "Does the descent into the realm of our 'archaeology' leave our tools intact?" (165). That Husserl remained within the confines of a transcendental phenomenology means that Merleau-Ponty must seize upon this question himself. To be sure, the question marks the culmination of his "break" from Husserl given that any methodology committed to transcendental phenomenology is unable to negotiate with the notion of a phenomenological archaeology, if we take such an archaeology as beginning before constitutive analysis. Here, Merleau-Ponty provides the evidence for this incipient archaeology in Husserl in the form of a "latent intentionality...more ancient than the intentionality of human acts" (165). The attempt to seal the abyss between consciousness and reality - an abyss that Husserl is never able to heal, despite the germs of a solution within his thought-leads Merleau-Ponty to circle the "interval" between Nature and mind.

After a detour into the pre-constitutive grounds of intercorporeality, MerleauPonty returns to the re-thinking of Husserl in an attempt frame "intentional analysis" as being concerned with both subjectivity and Nature (178). The dual intentionality, effectively orientated in both a horizontal and vertical pathway, leads to the principal problem of a phenomenology at the limits of its own inquiry, namely: "To understand its relationship to non-phenomenology" (178). As indicated, this aim crystalizes the very essence of what appears first as MerleauPonty's phenomenology of origins and then later his indirect or archaeological 
phenomenology. With it, the task of accounting for the elemental layer of existence, both constitutive of sense while at the same time being resistant to sense, serves as the leitmotif of brute being, as he writes:

What resists phenomenology within us - natural being, the "barbarous" source Schelling spoke of-cannot remain outside phenomenology and should have its place within it. The philosopher must bear his shadow, which is not simply the factual absence of future light (178).

This attempt to situate the non-phenomenological element within phenomenology itself will continue to occupy Merleau-Ponty up to his death.In the late essay on Husserl, it assumes an especially explicit presence in terms of preparing the groundwork for another phenomenology, a phenomenology that once again is already evident in Husserl in the form of "unveiling a back side of things that we have not constituted" rather than the earlier project of gaining "intellectual possession of the world" (180). As this earlier phenomenology comes to its own limit, the remains and remnants of another phenomenology come to the surface. There, Merleau-Ponty is able to trace "beings beneath our idealizations and objectifications which secretly nourish them and in which we have difficulty recognising noema" (180).

One such example of this secret world is the Earth. Indeed, it is precisely within this essay that Merleau-Ponty makes a fateful return to the Husserl fragment, describing the Earth as either the "“soil' or 'stem' of our thought as it is of our life" (180). The language of "soil" and "stem" explicitly bridges the interval between the Earth as both belonging to life (or Nature) and thought (or mind) concurrently. No longer simply the ground upon which the lived body is able to move and rest in the world, the Earth now becomes a duplicitous concept, as much "the matrix of our time as it is our space" (180). ${ }^{15}$

This interweaving of Nature and thought, and time and space, leads us to a sense of the Earth as the exemplary figure of Merleau-Ponty's archaeological phenomenology. It is both a spatial horizon of experience but also lodged in the verticality of a time before experience. This "proto-history" marks the alliance with Merleau-Ponty's notion of brute being, in that Earth as an archaeological site reveals both manifest and latent content, both a style of appearing and disappearing. ${ }^{16}$ Such a "wild-flowering world," discovered, as though by accident in Husserl, so Merleau-Ponty suggests, leads to a "rediscovery of that brute mind which, untamed by any culture, is asked to create culture anew" (181). This incipient dawn of a new ontology draws together Merleau-Ponty and Husserl in the same shadow, a shadow that is cast by Husserl but undoubtedly falls to Merleau-Ponty to expand.

It is clear from this account that "The Philosopher and His Shadow" marks Merleau-Ponty's move from an account of the Earth as co-constitutive with the 
lived body to the pre-constitutive soil placed in the interval between Nature and mind. Understood in this context, we come to see why Merleau-Ponty would speak of a "psychoanalysis of nature," as he would in The Visible and Invisible (Merleau-Ponty 1968, 267). Far from the inert background against which corporeal subjectivity is propelled into the world, the Earth beckons both a memorial and immemorial timescale, both a destructible and indestructible materiality, which at no point can be localised as a "correlate" to human experience alone, but instead marks an irrecoverable depth anterior to human experience. Such an archaeological thinking involves the framework of a psychoanalysis insofar as the concept of "latent intentionality" belongs to an anonymous life rather than the personal experience of life itself. At the intersection of Nature and mind, psychoanalysis locates a blind spot structuring consciousness without ever being wholly accessible to consciousness. This is possible thanks to the fact the Earth, considered as both an archaeological and phenomenological concept, retains the non-phenomenological dimension of Nature precisely within the field of phenomenology.

\author{
Dylan Trigg \\ dylan.trigg@ucd.ie
}

\title{
REFERENCES:
}

Barbaras, Renaud. The Being of the Phenomenon: Merleau-Ponty's Ontology. Trans. Leonard Lawlor and Ted Toadvine. Bloomington: Indiana University Press, 2004.

Heidegger, Martin. Being and Time. Trans. Joan Stambaugh. Albany: SUNY Press, 1996.

Husserl, Edmund. The Crisis of European Science and Transcendental Phenomenology. Trans. David Carr. Evanston: Northwestern University Press, 1970.

Lawlor, Leonard. Thinking Through French Philosophy: The Being of the Question. Bloomington: Indiana University Press, 2003.

Madison, Gary Brent. The Phenomenology of Merleau-Ponty: A Search for the Limits of Consciousness. Athens: Ohio University Press, 1990.

Merleau-Ponty, Maurice. Husserl at the Limits of Phenomenology. Trans. John O'Neil et al. Evanston: Northwestern University Press, 2002.

- Nature: Course Notes from the College de France. Trans. Robert Vallier. Evanston: Northwestern University Press, 2003.

- "Preface to Hesnard's L'Oeuvre de Freud," in Merleau-Ponty and Psychology. Trans. Alden L. Fisher. Atlantic Highlands: Humanities Press, 1993.

- The Phenomenology of Perception. Trans. Donald Landes. London: Routledge, 2012.

- The Primacy of Perception. Trans. William Cobb. Evanston: Northwestern University Press, 1964a.

- Signs. Trans. Richard McCleary. Evanston: Northwestern University Press, 1964b.

- Texts and Dialogues: On Philosophy, Politics, and Culture. Ed. Hugh Silverman. Atlantic Highlands: Humanities Press, 1992. 
- Themes From the Lectures at the Collège de France 1952-1960. Trans. John O'Neil. Evanston: Northwestern University Press, 1970.

- The Visible and the Invisible. Translated by Alphonso Lingis. Evanston: Northwestern University Press. 1968.

Steinbock, Anthony. Home and Beyond: Generative Phenomenology After Husserl. Evanston: Northwestern University Press, 1995.

- "Merleau-Ponty's Project of Transcendental History and Transcendental Geology," in Merleau-Ponty: Difference, Materiality, Painting.Ed. Véronique M. Fóti. Atlantic Highlands: Humanities Press, 2000.

Toadvine, Ted. Merleau-Ponty's Philosophy of Nature. Evanston: Northwestern University Press, 2009.

Toadvine, Ted and Embree, Lester. Merleau-Ponty's Reading of Husserl. New York: Springer, 2002.

Toadvine, Ted and Lawlor, Leonard. The Merleau-Ponty Reader. Evanston: Northwestern University Press, 2007.

Trigg, Dylan. "The Body of the Other: Intercorporeality and the Phenomenology of Agoraphobia," in Continental Philosophy Review, Volume: 46, Issue: 3, 413-429.

Vallier, Robert. "Être Sauvage And The Barbaric Principle: Merleau-Ponty's Reading of Schelling," in Chiasmi International 2. Paris: Vrin, 2000.

\section{NOTES:}

1 My thanks to the Irish Research Council for their support funding this research, which is herein gratefully acknowledged.

2 Merleau-Ponty's engagement with the Earth fragment is evident even in the Phenomenology of Perception, where it makes an appearance in the chapter on time (Merleau-Ponty 2012, 453). Thanks to the research of Herman Van Breda, we know of the details of Merleau-Ponty's early trips to the Husserl Archives in Leuven, where these unpublished Husserl materials would have been available to him (Merleau-Ponty 1992). At the other end of timescale, the final mention of the fragment can be found in the significant working note form June $1^{\text {st }} 1960$ concerning "transcendental geology" (Merleau-Ponty 1968, 258-259). The note is significant given the role Merleau-Ponty accords to the Earth in establishing the material foundations of history (See also Steinbock's incisive commentary on the note [Steinbock 2000, 90-111]).

3 The question of where Husserl ends and where Merleau-Ponty, although a fascinating question, is one that we have to leave aside in this paper. Suffice to say that the problem was already on Merleau-Ponty's mind during this period in his thinking, remarking in the key essay on Husserl that "there must be a middle-ground on which the philosopher we are speaking about and the philosopher who is speaking are present together, although it is no possible even in principle to decide at any given moment just what belongs to each" (Merleau-Ponty 1964b, 270). (See also Toadvine and Embree 2002).

4 On Schelling's influence on Merleau-Ponty's account of wild being see Vallier 2000.

5 On the semantic ambiguities of "Boden" as both ground and foundation concurrently see Steinbock 1995, 110.

6 This side-stepping of the first point is not only for the sake of maintaining a thematic focus. It is also due in large to Husserl's dismissal of his own response to the Earth's relation to another Earth; namely, by rendering the Earth divisible. In this way, an "inner space" is created that gives rise to a series of earthly body parts. Husserl is not convinced, and goes so far as to question if "the difficulty of the constitution of the earth as a body [is] hopelessly exaggerated?" (122). As it stands, the question is left unanswered and soon abandoned. 
7 To do justice to these questions, we would need not only a conceptual analysis of Earth as it figures in both Merleau-Ponty and Husserl's thinking, but also an applied phenomenology of the body in a multiplicity of affective states. In this instance, to speak of the experience of the Earth as "groundless" would lead us - almost certainly via Heidegger's account of "groundless floating" - toward the experience of anxiety (Heidegger 1996, 158). A study of this relation between Earth, ground, and anxiety is currently in preparation (cf. Trigg 2013).

8 My thanks to the anonymous reviewer of this paper for pointing this connection out.

9 For more on Merleau-Ponty's usage of the term "archaeology" see especially Leonard Lawlor's incisive discussion of the theme in chapter two of his Thinking Through French Philosophy: The Being of the Question (Lawlor 2003). Gary Brent Madison's earlier treatment of the concept is also worthy of note (Madison 1990, 138-139). Merleau-Ponty's own usage of archaeology can be found throughout his later works, especially "The Philosopher and His Shadow," the course notes on nature, and the late lectures on Husserl (Merleau-Ponty 1964b, 2003, 2002). Of special note is another of Merleau-Ponty's late works concerning the relation between phenomenology and psychoanalysis, which I discuss below (Merleau-Ponty 1993). Finally, we must also mention the passing reference to archaeology written during this time in his "Five Notes on Claude Simon," which are to be found in Texts and Dialogues (MerleauPonty 1992). There, he will make the connection between an "Archaeology of thought" as also being "of the future as well" (142).

10 I owe this insight concerning Husserl's geological background to Dermot Moran.

11 On the theme of "resistance" in Merleau-Ponty's account of Nature, see Ted Toadvine Merleau-Ponty's Philosophy of Nature (Toadvine 2009, 50).

12 For the reasons stated, I am included to agree with Lawlor's tentative suggestion that Merleau-Ponty's usage of archaeology may just as easily refer to Freudian analysis (Merleau-Ponty 2002, xxxv).

13 On the importance of this essay in Merleau-Ponty's overall relation to Husserl, see Ted Toadvine's exemplary article, "Leaving Husserl's Cave?" (Toadvine and Embree, 2002, 71-94). Toadvine makes the argument in this chapter that in contending with a phenomenology at the limits, "an archaeology of its past" is involved, which requires less a dialogue with Descartes as the axiomatic figure in Husserlian phenomenology and more with Plato.

14 On Merleau-Ponty's "unthought thought” (impensé), see Barbaras 2004, 69.

15 Here, we cannot help but note in relation to this passage Merleau-Ponty's account of "transcendental geology" as involving "the very time that is space, this very space that is time" (Merleau-Ponty 1968, 258).

16 For this reason, Lawlor is surely right to suggest that "this originary soil is the unconscious," reinforcing here the link between archaeology and psychoanalysis as both concerned with "what resists phenomenology" precisely through being implicated by phenomenology (Lawlor 2003, 32). 